\title{
River response to climate and sea level changes during the Late Saalian/Early Eemian in northern Poland - a case study of meandering river deposits in the Chłapowo cliff section
}

\author{
Damian Moskalewicz ${ }^{1}$, Robert J. Sokołowski ${ }^{*}$ \& Stanisław Fedorowicz ${ }^{1}$ \\ ${ }^{1}$ Department of Geomorphology and Quaternary Geology, Institute of Geography, University of Gdańsk, \\ al. Bażyńskiego 4, 80-952 Gdańsk, Poland \\ ${ }^{2}$ Department of Marine Geology, Institute of Oceanography, University of Gdańsk, al. Piłsudskiego \\ 46, 81-378 Gdynia, Poland \\ *corresponding author, e-mail: r.sokolowski@ug.edu.pl
}

\begin{abstract}
Fluvial sediments in the Chłapowo cliff section were studied in order to reconstruct their palaeoflow conditions and stratigraphical position. Lithofacies, textural and palaeohydraulic analyses as well as luminescence dating were performed so as to achieve the aim of study. Sedimentary successions were identified as a record of point bar cycles. The fluvial environment probably functioned during the latest Saalian, shortly after the retreat of the Scandinavian Ice Sheet. Discharge outflow was directed to the northwest. The river used the older fluvioglacial valley and probably was directly connected to the Eem Sea. Good preservation and strong aggradation of point-bar cycles were related to a rapid relative base level rise. The meandering river sediments recognised showed responses to climate and sea level changes as illustrated by stratigraphical, morphological and sedimentological features of the strata described. The present study also revealed several insights into proper interpretation of meandering fluvial successions, in which the most important were: specific lithofacies assemblage of GSt (St, Sp) $\rightarrow \mathrm{Sl} \rightarrow \mathrm{SFrc} \rightarrow \mathrm{Fm}$ (SFr) and related architectural elements: channel/sandy bedforms $\mathrm{CH} / \mathrm{SB} \rightarrow$ lateral accretion deposits $\mathrm{LA} \rightarrow$ floodplain fines with crevasse splays FF (CS); upward-fining grain size and decreasing content of denser heavy minerals; estimated low-energy flow regime with a mean depth of 1.6-3.3 m, a Froude number of 0.2-0.4 and a sinuosity of 1.5.
\end{abstract}

Keywords: point-bar succession, meandering fluvial system, Quaternary geology, fluvial sedimentology, Eemian Sea

\section{Introduction}

In the Pleistocene glacial record, meandering rivers were not so widespread as were braided rivers, in areas affected by advances of the Scandinavian Ice Sheets. During this period, conditions for the evolution of meandering river patterns in valley systems were provided in times marked by proper environmental settings, mostly during interglacials (Vandenberghe, 2001, 2003; Huisink et al., 2002; Vandenberghe \& Woo, 2002).
Complete cycles of meandering rivers can be preserved only under specific conditions, the most important of which include: topography of the palaeovalley system, sediment supply, flow characteristics, climate, available accommodation space, eustatic sea level fluctuations or tectonic movements and position of the ice sheet margin (Blum \& Tornqvist, 2000; Mol et al., 2000; Catuneanu, 2006; Toucanne et al., 2009; Blum et al., 2013; Ghinassi et al., 2014). During field work, a Pleistocene succession with well-preserved point-bar sediments 
was encountered in the Chłapowo cliff section. The present study aimed to: 1 ) reconstruct palaeoflow conditions of an ancient meandering river, 2) recognise the palaeogeographical setting and age of the system, and 3) discuss the reasons behind the good preservation of fluvial strata.

\section{Geological setting}

The study area is situated in the central part of the southern Baltic coast, $35 \mathrm{~km}$ to the north of Gdynia (Fig. 1), and covers the Chłapowo cliff section along the coastline between the towns of Władysławowo and Jastrzębia Góra. Smaller outcrops also exist in erosional ravines that cut into the cliff. Quaternary sediments cover Eocene, Oligocene and Miocene deposits with a total thickness of approximately $120 \mathrm{~m}$. Eocene and Oligocene strata, deposited in an epicontinental sea, comprise mudstones, sands and muds, in places enriched in amber (Kramarska et al., 2002; 2008). Miocene sediments are represented by quartz-mica sands and lignite and attain a thickness of c. $80 \mathrm{~m}$, including up to $30 \mathrm{~m}$ that are accessible at several places along the cliff (Marzec \& Woźny, 1972). Lithofacies analysis showed the strata to have originated in a lowenergy fluvial environment and their sedimentation probably occurred within a meandering system (Moskalewicz \& Sokołowski, 2014). Miocene layers are found underneath a 30-m-thick Pleistocene series, the base of which is formed by a distinct erosional boulder pavement of Scandinavian erratics. Pleistocene sediments change laterally within the cliff outcrop; however, their upper part commonly includes a 2-m-thick till layer, while other parts are generally dominated by sands and gravels, forming two series of fluvial deposits. The lower, gravelly succession was interpreted as a record of a braided river system with a westerly outflow (Moskalewicz \& Sokołowski, 2014). The overlying sandy fluvial strata are the subject of the present study. The stratigraphy of these sediments has not yet been well established, although TL dating (162.9 $\pm 24.4-$ $322.2 \pm 48.3 \mathrm{ka}$ ) indicates that they are assignable to the Saalian glaciation (Olszak, 1996).

\section{Methods}

Sandy sediments in the Chłapowo cliff section were subjected to lithofacies, grain size, heavy mineral and palaeohydraulic analyses. A lithofacies code that follows Miall (1996) and Zieliński (1998) is defined in Figure 2. For each lithofacies type identified in the field, at least one sediment sample was collected for laboratory analysis. Sieving was done to obtain grain-size distributions and median values. The medium-grained $(0.18-0.25 \mathrm{~mm})$ sand fraction was also subjected to heavy mineral analysis, involving separation by sodium polytungstate at a specific density of $2.85 \mathrm{~g} / \mathrm{cm}^{3}$ and identification of minerals under a petrographic microscope. A minimum of 300 transparent minerals were identified in each sample. Opaque minerals were also counted to compare their percentage to that of transparent minerals. Determination of the absolute age of sediments used a TL dating method at Gdansk laboratory to verify previous data (Olszak, 1996). The methodology applied follows that of Fedorowicz

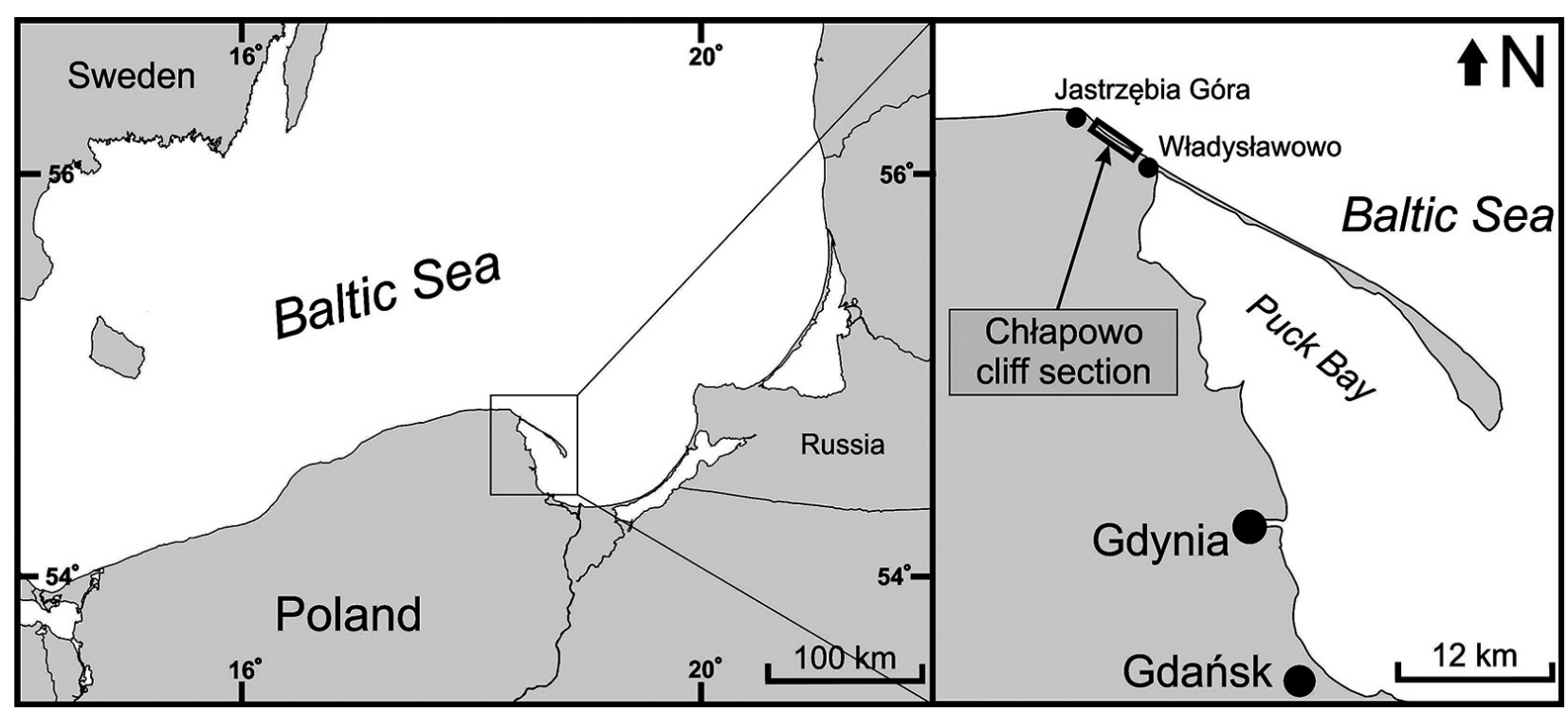

Fig. 1. Location of the Chłapowo cliff section. 
et al. (2013; see detailed discussion in Fedorowicz, 2006).

Palaeohydraulic parameters were estimated on the basis of the thickness of sedimentary units measured, in combination with grain size and palaeocurrent data. Most geometric parameters of meandering palaeochannels can simply be reconstructed by a study of sedimentary successions during field work (Williams, 1984; Bridge \& Tye, 2000; Ito et al., 2006; Khan \& Tewari, 2011; Ghinassi et al., 2014). Equations were chosen in consideration of the type of palaeochannel pattern recognised in ancient fluvial strata. None of the parameters presented was measured directly, due to insufficient outcrop width (except for directional analysis and thickness). Ghinassi et al. (2014) discussed this problem, and showed that values obtained by empirical equations allowed an adequate approximation of channel geometric features.

Directional analysis was performed so as to estimate channel sinuosity and mean palaeocurrent vector (Bridge et al., 2000). Channel sinuosity (sn) was calculated using the following empirical equations:

$$
\mathrm{sn}=4.84 /\left(4.84-\mathrm{fi}^{2}\right)
$$

where fi is half of the maximum palaeocurrent range in radians. The mean palaeocurrent vector was computed according to the standard method (Tucker, 2003).

To determine mean channel depth (D) we used the following formula due to a partially eroded point-bar cyclotheme, which involves its thickness $\left(\mathrm{T}_{\mathrm{PB}}\right)$ :

$$
\mathrm{D}=0.65 \mathrm{~T}_{\mathrm{PB}}
$$

We used the coefficient 0.65 , related to further erosion and compaction of sediment, as the mean value from formulas applied by Cotter (1971), Morton \& Donaldson (1978), Allen \& Mange-Rajetzky (1982) and Bridge \& Tye (2000).

The thickness of point-bar deposits, interpreted as the bankfull channel depth (Bridge \& Tye, 2000), was used to estimate channel belt width (CBW), following Bridge \& Mackey (1993) and Ito et al. (2006):

$$
\mathrm{CBW}=59.9 \mathrm{~T}_{\mathrm{PB}}^{1.8}
$$

Channel width (W) was calculated as a function of mean depth (D) and channel sinuosity (sn), following Williams (1986):

$$
\mathrm{W}=96 \mathrm{D}^{1.23} \mathrm{sn}^{-2.35}
$$

Meander wavelength (L) was approximated according to Leopold \& Wolman (1960):

$$
\mathrm{L}=10.9 \mathrm{~W}^{1.01}
$$

Mean annual discharge (Q) was calculated from Schumm's (1972) formula:

$$
\mathrm{Q}=\mathrm{W}^{2.43} / 18(\mathrm{~W} / \mathrm{D})^{1.13}
$$

One of the challenges in interpretation of ancient fluvial systems is to determine the palaeoslope of the channel. Most small outcrops do not provide any opportunity for direct measurements. A relationship between slope, discharge and channel depth was proposed by Leopold \& Wolman (1957a, b, 1960), but later variations that also involve grain size diameter can be used successfully to derive other parameters from the thickness of strata. We used Ferguson (1987) formula to approximate palaeoslope (S):

$$
S=0.0049 \mathrm{~d}_{50}^{0.52} \mathrm{Q}^{-0.21}
$$

The roughness coefficient (n) was approximated according to Maizels (1983):

$$
\mathrm{n}=0.039 \mathrm{~d}_{50}^{0.167}
$$

The flow velocity of stream (V) was determined with the Gauckler-Manning formula:

$$
V=\left(R^{0.067} S^{0.5}\right) n^{-1}
$$

where $\mathrm{R}$ is the hydraulic radius interpreted as mean flow depth (D), due to the cross-sectional geometry of the meandering channel.

The velocity obtained was used to calculate the Froude number (Fr), where $\mathrm{g}$ is acceleration due to gravity:

$$
\mathrm{Fr}=\mathrm{V}(\mathrm{gD})^{-0.5}
$$

\section{Results}

Three depositional units (U1-U3) were investigated in the central part of the cliff section (Fig. 2) on the basis of major erosive boundaries and lithofacies successions. TL dating (Fig. 2, Table 1) shows that these sediments could be linked to the period from the late Saalian glaciation to the start of the Eemian interglacial. Results of dating showed an interval 
age of $120 \pm 18-265 \pm 40 \mathrm{ka}$. However, the oldest date $(265 \pm 40 \mathrm{ka})$ is not representative. Due to the high sedimentation rate, sediment probably was not adequately zeroed, which led to an increase of the age of the strata. Details of palaeohydraulic parameters are presented in Table 2. Sinuosity, calculated for all three units together, amounted to 1.5. The other palaeohydraulic parameters are described below.

\subsection{Unit 1}

Unit 1, with a mean thickness of $4.2 \mathrm{~m}$, comprises a succession of $\mathrm{St} \rightarrow \mathrm{Sp} \rightarrow \mathrm{Sl}$ lithofacies capped by a 20-cm-thick SFr lithofacies (Fig. 2). The St litho- facies attains a maximum thickness of $3 \mathrm{~m}$. The $\mathrm{Sl}$ lithofacies, with some organic detritus, is eroded in the upper part. With an erosional boundary that is overlain by a mud layer (Fm) of variable thickness, ranging from several to $30 \mathrm{~cm}$. In turn this is overlain by a $c$. 20-cm-thick layer of well-sorted fine sands with ripple cross-lamination (SFr). This layer is truncated by a second erosional boundary. Median grain size decreases upwards in the unit, from $0.22 \mathrm{~mm}$ in the St lithofacies to $0.19 \mathrm{~mm}$ in the upper part of the Sl lithofacies and $0.05 \mathrm{~mm}$ in the SFr lithofacies. Heavy mineral analysis shows a predominance of garnet $(40 \%)$, pyroxene $(31 \%)$ and amphibole $(17 \%)$. The ratio of opaque to transparent minerals attains a mean value of 0.44 . The

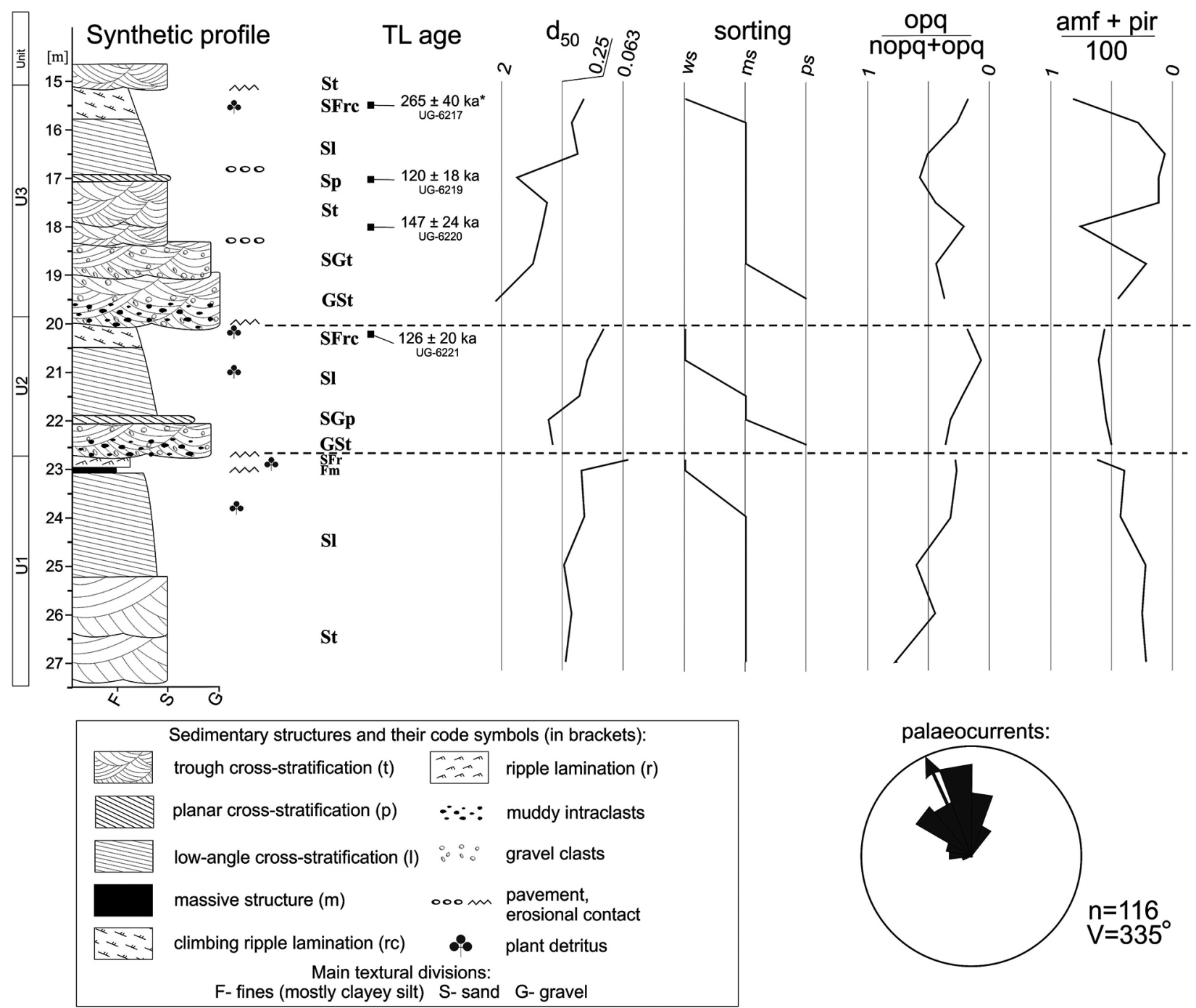

Fig. 2. Sedimentological characteristics of the Chłapowo cliff section. $\mathrm{D}_{50}$ is median grain size in mm; sorting is presented as: ws - well sorted, ms - moderately sorted, ps - poorly sorted; opq/nopq+opq is the ratio of opaque heavy mineral content; amf+pir/100 is the ratio of amphibole and pyroxene total content, being an index of less resistant heavy mineral content. Note the specific trends within individual sedimentary units. * - This date is not representative; the sediment probably was not adequately zeroed. 
Table 1. TL dating results provided by the Gdańsk laboratory with radionuclide concentrations (Bq/ kg) and dose rate, equivalent dose and TL age.

\begin{tabular}{cccccccc}
\hline $\begin{array}{c}\text { TL sample } \\
\text { \& depth }[\mathrm{m}]\end{array}$ & $\begin{array}{c}\text { No lab. } \\
\mathrm{UG}\end{array}$ & $\begin{array}{c}{ }^{226} \mathrm{Ra} \\
{[\mathrm{Bq} / \mathrm{kg}]}\end{array}$ & $\begin{array}{c}{ }^{232} \mathrm{Th} \\
{[\mathrm{Bq} / \mathrm{kg}]}\end{array}$ & $\begin{array}{c}{ }^{40} \mathrm{~K} \\
{[\mathrm{~Bq} / \mathrm{kg}]}\end{array}$ & $\begin{array}{c}\text { Dose rate } \mathrm{d}_{\mathrm{r}} \\
{[\mathrm{Gy} / \mathrm{ka}]}\end{array}$ & $\begin{array}{c}\text { Eq. dose } \mathrm{d}_{\mathrm{e}} \\
{[\mathrm{Gy}]}\end{array}$ & $\begin{array}{c}\text { TL age } \\
{[\mathrm{ka}]}\end{array}$ \\
\hline $\mathrm{CH}-15.5$ & 6217 & $4.7 \pm 0.4$ & $5.2 \pm 0.4$ & $523 \pm 37$ & $1.54 \pm 0.14$ & $407.8 \pm 41.6$ & $265 \pm 40$ \\
$\mathrm{CH}-17.0$ & 6218 & $4.2 \pm 0.3$ & $6.6 \pm 0.4$ & $601 \pm 38$ & $1.72 \pm 0.16$ & $206.9 \pm 22.1$ & $120 \pm 18$ \\
$\mathrm{CH}-18.0$ & 6220 & $4.4 \pm 0.3$ & $6.5 \pm 0.4$ & $472 \pm 35$ & $1.46 \pm 0.15$ & $214.0 \pm 23.1$ & $147 \pm 24$ \\
$\mathrm{CH}-20.2$ & 6221 & $6.1 \pm 0.4$ & $8.4 \pm 0.5$ & $470 \pm 38$ & $1.49 \pm 0.16$ & $188.1 \pm 19.3$ & $126 \pm 20$ \\
\hline
\end{tabular}

opaque mineral content generally displays an upward-decreasing trend, while amounts of pyroxene and amphibole increase upwards, form 32\% in the St lithofacies to $76 \%$ in the SFr lithofacies. Palaeocurrent analysis indicates a mean palaeoflow direction to the NNW. The mean depth of the palaeoflow was estimated at $2.9 \mathrm{~m}$, bankfull depth at $4.5 \mathrm{~m}$, mean velocity at $1 \mathrm{~m} / \mathrm{s}$ and the Froude number at 0.19 .

\subsection{Unit 2}

Unit 2 is formed by a GSt $\rightarrow \mathrm{SGp} \rightarrow \mathrm{Sl} \rightarrow \mathrm{SFrc}$ lithofacies succession with a total thickness of $2.5 \mathrm{~m}$ (Figs 2 and 3). Within the poorly sorted, coarse-grained sediments (GSt, SGp), which attains a median grain size of $0.38-0.44 \mathrm{~mm}$, numerous muddy intraclasts of upward-decreasing frequency and diameter (maximum $11 \mathrm{~cm}$ ) were recorded. Fine-grained sediments in the upper part of unit 2 are partially eroded. The median grain size of the Sl and SFrc facies ranges between 0.12 and $0.19 \mathrm{~mm}$. Pyroxene (41\%), amphibole $(27 \%)$ and garnet $(27 \%)$ are the commonest heavy minerals. Towards the top of the unit, the content of opaque minerals, with a mean ratio of 0.25 , generally decreases, in contrast to the slightly increasing frequencies of pyroxene and am-

Table 2. Palaeohydraulic parameters calculated for pointbar sediments in the Chłapowo cliff section. ${ }^{1}$ - input data.

\begin{tabular}{|c|c|c|c|}
\hline Unit & U1 & U2 & U3 \\
\hline Paleocurrent range [degrees] $^{1}$ & & $248-34$ & \\
\hline $\begin{array}{l}\text { Thickness of point-bar succes- } \\
\text { sion, } T_{P B}[\mathrm{~m}]^{1}\end{array}$ & 4.5 & 2.5 & 5.0 \\
\hline Median grain size, $\mathrm{d}_{50}[\mathrm{~mm}]^{1}$ & 0.179 & 0.254 & 0.726 \\
\hline Sinuosity, sn & & 1.5 & \\
\hline Mean depth, D [m] & 2.9 & 1.6 & 3.3 \\
\hline Bankfull depth, $\mathrm{D}_{\max }=\mathrm{T}_{\mathrm{PB}}[\mathrm{m}]$ & 4.5 & 2.5 & 5.0 \\
\hline Width of the channel, W [m] & 139 & 67 & 158 \\
\hline Channel belt width, CBW [m] & 898 & 312 & 1085 \\
\hline Meander length, L [m] & 1587 & 765 & 1809 \\
\hline Mean discharge, $\mathrm{Q}\left[\mathrm{m}^{3} / \mathrm{s}\right]$ & 114 & 23 & 152 \\
\hline Slope, S [\%o] & 0.74 & 1.24 & 1.44 \\
\hline Mean flow velocity, $\mathrm{V}[\mathrm{m} / \mathrm{s}]$ & 1.0 & 1.6 & 2.3 \\
\hline Froude number, Fr & 0.19 & 0.39 & 0.40 \\
\hline
\end{tabular}

phibole. Palaeocurrent analysis indicates a mean palaeoflow directed to the north. The mean depth of the palaeochannel is estimated at $1.6 \mathrm{~m}$, bankfull depth at $2.5 \mathrm{~m}$, mean velocity at $1.6 \mathrm{~m} / \mathrm{s}$, and the Froude number at 0.39 .

\subsection{Unit 3}

Unit 3 has an erosional basal contact. The unit comprises gravelly and sandy sediments, $5 \mathrm{~m}$ in total thickness, with a preserved succession of $\mathrm{GSt} \rightarrow \mathrm{SGt} \rightarrow \mathrm{St} \rightarrow \mathrm{Sp} \rightarrow \mathrm{Sl} \rightarrow \mathrm{SFrc}$ (Fig. 3A). Two lines of boulders, which are concordant with the lithofacies bedding, are present within the succession (Fig. 3E). Sediments of the trough cross strata, $3 \mathrm{~m}$ in thickness, are poorly sorted in the lower part, but sorting becomes better upwards. They also include a large number of muddy intraclasts which display, similar to unit 2, an upward-decreasing frequency and diameter. The median grain size of the strata varies from $2.48 \mathrm{~mm}$ in the GSt lithofacies to $0.14 \mathrm{~mm}$ in the SFrc lithofacies. Heavy mineral analysis reveals a predominance of garnet $(43 \%)$, pyroxene $(28 \%)$ and amphibole (22\%). The ratio of opaque to transparent minerals attains a mean value of 0.37 . Within the trough cross strata, heavy mineral contents are variable. In the upper part of the succession the ratio of opaque to transparent minerals shows a decreasing trend, while amounts of less resistant minerals greatly increase. Palaeocurrent analysis indicated a mean palaeoflow direction to the northwest. The mean depth of the palaeochannel is estimated at $3.3 \mathrm{~m}$, bankfull depth at $5 \mathrm{~m}$, mean velocity at 2.3 $\mathrm{m} / \mathrm{s}$, and the Froude number at 0.4 .

\section{Discussion}

\subsection{Palaeoenvironment and palaeohydrology}

Gravels and coarse sands with trough cross-stratification (GSt, SGt) are interpreted as bedforms that developed in the deepest part of a channel (Fig. 4B). Poor sorting of these sediments suggests a high-en- 
ergy flow and relatively rapid sedimentation (Ghazi \& Mountney, 2009; Ghinassi et al., 2014). An abundance of muddy intraclasts provide evidence of fluvial reworking of floodplain deposits.

The GSt and SGt deposits in units 2 and 3 are overlain by sand with a planar cross-stratification (Sp) lithofacies that may be a record of waning flow. This lithofacies represents small migrating transverse bars or sand waves (Allen, 1964; Todd \& Went, 1991).

The medium-grained sand with trough cross-stratification (St) in units 1 and 3 is related to the formation of three-dimensional dunes in a relatively deep channel zone - the thalweg (Allen, 1964;

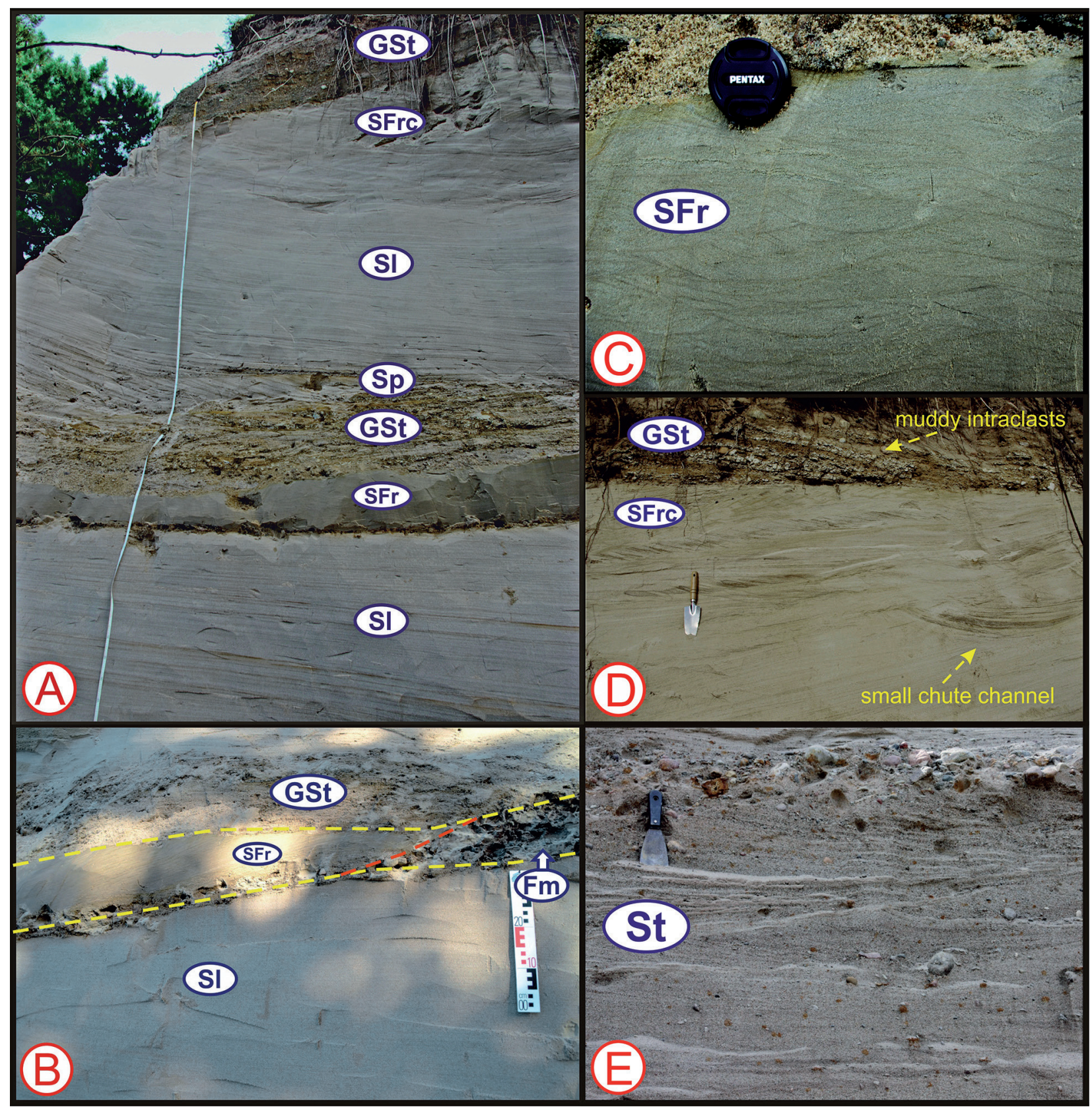

Fig. 3. Photographs showing particular features of point-bar sediments.

A - Transition of lithofacies within sedimentary cycles. Each cycle begins with trough cross-stratified gravels and sands, passing into sands of planar, low-angle cross-stratification and climbing-ripple cross-lamination. Fine overbank lithofacies are also preserved; B - Lateral contact of Fm overbank lithofacies (right side) with SFr lithofacies interpreted as part of a crevasse splay; C - Internal structure of crevasse splay deposits; D - Upper part of point-bar cycles with a small-scale chute channel and climbing-ripple cross-lamination. Note the high content of intraclasts in the lithofacies above the erosional boundary; E - Internal features of trough cross-stratification without intraclasts. 

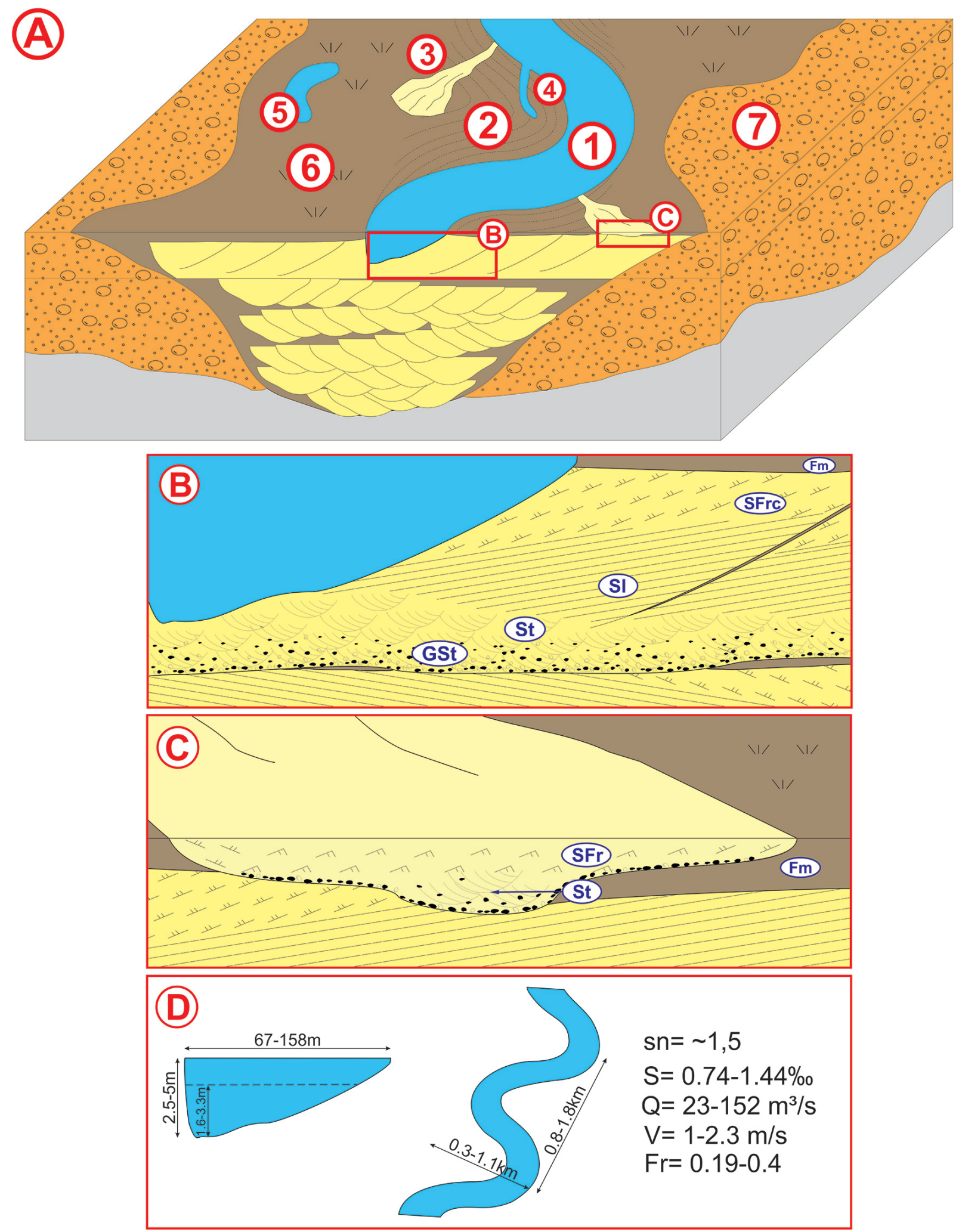

Fig. 4. Interpretative model of the sedimentary environment interpreted.

A - General view of the most important architectural elements: 1- channel, 2 - point bar, 3 - crevasse splay, 4 - chute channel, 5 - cut-off meander, 6 - poorly vegetated muddy floodplain, 7 - older terrace; B - Lithofacies succession indicating a typical cycle of meandering river; $\mathrm{C}$ - Conceptual model of crevasse splay lithofacies; D - Most important palaeohydraulic parameters and channel geometry dimensions. All figures are not to scale. 
Ashley, 1990; Collinson, 1996). The lack of muddy intraclasts and medium sand may reflect sediment supply at the time of deposition, and probably is not related to a change of flow conditions.

Medium sands with planar, low-angle cross-stratification (Sl) were formed in the transition zone between deep and shallow parts of the channel. The medium sand texture, good sorting and normal grading, suggest a gradually decreasing flow energy vertically in the deposits. Lithofacies $\mathrm{Sl}$ was developed mostly under subcritical flow conditions, as a record of washed-out sand waves (Miall, 1996).

Fine silty sands with climbing-ripple lamination (SFrc) are evidence of low flow energy and sedimentation in shallow parts of the channel. The $\mathrm{Sl}$ and SFrc lithofacies occasionally include small troughs in their upper parts (Fig. 3), presumably associated with bending flow and development of small-scale chute channels (Ghinassi, 2011; Grenfell et al., 2014).

Massive muds (Fm) are interpreted as fine floodplain overbank deposits, developed in flood periods via suspended sediment transport and deposition. Poor preservation of the Fm lithofacies is linked to the reworking of fluvial sediments from the effect of lateral channel migration within an aggrading depositional environment. This explains why complete overbank successions with palaeosoil horizons are absent.

The SFr lithofacies is interpreted as part of a crevasse splay (Farrell, 2001; Van Huissteden \& Kasse, 2001). The lower boundary of this lithofacies was erosional; however, median grain size $(0,05 \mathrm{~mm})$ and well-sorted sediment indicate relatively slow and low-energy transport. The superposition to the Fm lithofacies and the erosional contact between them is also important. Palaeocurrents measured within the SFr lithofacies showed different directions of palaeoflows to the channel deposits, with a deviation of about tens of degrees. This interpretation is supported by the widespread, yet discontinuous abundance of this lithofacies within the entire fluvial succession exposed in the Chłapowo cliff section. All these features indicate river flow entering the proximal part of the floodplain. The general concept of crevasse splay formation is presented in Fig. 4C.

Particular units provide a record of cyclic sedimentation, commonly observed in fluvial systems. Successions similar to GSt (St, Sp) $\rightarrow \mathrm{Sl} \rightarrow \mathrm{SFrc} \rightarrow \mathrm{Fm}$ (SFr) have been widely described for meandering river sediments of different ages (Collinson 1996; Miall 1996; Zieliński 1998). In Miall's (1985, 1996) terminology, the succession described above corre- sponds to the following transition of architectural elements: channel/sandy bedforms $\mathrm{CH} / \mathrm{SB} \rightarrow$ lateral accretion deposits LA $\rightarrow$ floodplain fines with crevasse splays FF (CS).

Meandering processes imposed permanent reworking of sediments, resulting in the low preservation potential of fine floodplain deposits. Abundant intraclasts in trough cross strata are fragments eroded from the floodplain indicative of lateral erosion of fine-grained floodplain deposits. If the sedimentary record covers only channel sediments, correct lithofacies-based interpretation of a fluvial environment may be hindered, as lower parts of sedimentary cycles in braided and meandering rivers could be similar in some respects. For example, both can include St and Sp assemblages, being a record of migrating sand bedforms in the channel (Allen, 1964; Crowley, 1983; Leleu et al., 2009), which is noted primarily in the comparison of straight segments (thalweg zones) of meandering rivers and deep sand-bed braided rivers (Stewart, 1981). Another similarity is the presence of the Sl lithofacies, formed either as the upper part of point bars or as low, washed-out central bars in sand-bed braided rivers (Cowan, 1991).

Sedimentary cycles of meandering rivers display upward-fining trends (Nanson, 1980), related to the distribution of flow energy in relatively deep channels with varied bottom morphology. Coarser particles of sand and gravel were deposited in the thalweg, while finer fractions aggraded in the upper parts of point bars. Heavy mineral analysis indicates that abundances of more/less resistant minerals vary within cycles, showing an enrichment of pyroxenes and amphiboles in the upper parts of cycles. The content of non-opaque minerals increases upwards in the cycles, in contrast to the generally denser opaque minerals (Mange \& Maurer, 1992). Heavy mineral distribution depends of the energy that is required for their transport. If the upper parts of sedimentary cycles are eroded, heavy mineral composition is similar in meandering and braided river sediments (Zieliński \& Goździk, 2001), particularly when such meandering rivers functioned in a cold, post-glacial period. In that case, the content of particular heavy minerals should be interpreted carefully on account of a marked relationship between their composition and river pattern evolution (Weckwerth \& Chabowski, 2013).

A relationship between the trend of fining-upward grain size (one of the main indicators of meandering fluvial environments) and increasing amounts of less resistant minerals, e.g. of amphibole and pyroxene groups was established during the present study. Both gradual, vertical trends as 
recorded in sedimentary successions are valuable indicators of decreasing flow energy (more precisely, shear stress) that may be related to a meandering style of sedimentation.

Palaeocurrent data obtained for particular units show great dispersion in all directions. However, values obtained only from cross-stratified deposits suggest a relatively consistent palaeoflow vector, with distribution attaining several tens of degrees in the northerly and northwesterly direction (Fig. 2). Such results can be interpreted as a complex multi-directional flow, most likely associated with a meandering rather than a braided river pattern (Ghazi \& Mountney, 2009; Salamon \& Zieliński, 2010; Fustic et al., 2012). Results of channel slope estimates (0.74-1.44\%o) most likely could not be linked to a braided system. However, with reference to Hartley et al. (2010), identification of single sinuous, multiple sinuous or sinuous-to-braided channel patterns seems to be more appropriate. Sinuosity, estimated at 1.5 , is a lower boundary value for sinuous rivers (Rust, 1978; Miall, 1996) and may be identified with meandering rivers (Teisseyre, 1985, 1991; Zieliński, 2014). During mean stages, the depth of the channel was 1.6-3.3 m, discharge $22.9-151.6 \mathrm{~m}^{3} / \mathrm{s}$ and flow velocity $1-2.3 \mathrm{~m} / \mathrm{s}$. The estimated palaeohydraulic parameters (Tab. 2, fig. 4) show that the river functioned within a low-energy system with subcritical flows. The flow regime changed during flood periods, but values presented indicate a meandering rather than a braided fluvial environment.

\subsection{Causes of aggradation and sedimentation style}

Lithofacies assemblages and preliminary stratigraphical allocation suggest that the river functioned in a cold period, shortly after the Saalian glaciation. Mojski (2005), who summarised investigations of Quaternary sediments in Poland, opined that the morphological surface of Polish Lowlands was partially re-organising following successive glaciations and that most major rivers in Poland generally had constant and comparable outflow directions through the entire Quaternary period.

The river probably evolved in the same valley from a braided pattern during a period of transformation from glacial to interglacial settings. Kozarski \& Rotnicki (1977) showed a braided river development at the end of glaciation in the Prosna valley in the Polish Lowlands. Later, a river with large meanders came into being, which then evolved into a medium-scale meandering system.
Similar observations in western Europe and North America were made by other authors, who proved that low-energy meandering patterns arose mostly after deglaciations under climatic and sea level changes (Kozarski et al., 1988; Mol, 2000; Blum \& Tornqvist, 2000, Gibbard \& Lewin, 2002; Kasse et al., 2003). The regional evolution of river patterns with reference to glaciation events and sea level changes is presented in Figure 5.

We deduced that fluvial sediments preserved in the Chłapowo cliff section represent the downstream part of a regional river (c. 150-200 km long) with relatively strong flow power. The depth of the river and the determined discharge values surpass modern examples (e.g., Piaśnica, Łeba and Łupawa). This suggests that the river had a diverse discharge network with a lot of tributaries, probably constituting one of the major regional rivers that extended at least from the Pomeranian Lakelands to the Eem Sea.

Based on recent views on Eem Sea palaeogeography (Funder et al., 2002; Head et al., 2005; Makows$\mathrm{ka}, 2009$ ), the transgression reached the area close to the study site. However, there are not enough data on Eem Sea deposits on the northern and western ends of Chłapowo cliff. Reconstructions of river valley system in Poland also show that river systems with an outflow directed to the north-northwest may not have been possible (Marks, 2005; Makowska, 2009). Meandering fluvial sediments recognised in the Chłapowo cliff section demonstrate that existing palaeogeographical models may need to be revised; however, more data from other sites are essential for a proper palaeogeographical reconstruction.

Subsequent fluvial cycles with a similar record of thickness, geometry and lithofacies succession, with minor presence of an overbank subenvironment and a lack of palaeosols, indicate an aggradation stacking pattern (Blum \& Tornqvist, 2000). Sediment supply to the Eem Sea was probably high, due to early erosion in the young post-glacial landscape. The river functioned during a cold period, which is demonstrated by the weak chemical erosion of heavy minerals (i.e., high content of pyroxenes and amphiboles) and the lack of organic matter within the overbank lithofacies. Therefore, according to Blum \& Tornqvist (2000), when considering stratigraphical, morphological and sedimentological responses, a direct influence of climatic changes on the evolution of the river pattern, probably was less important than of sea level change.

As a rule, the final phases of deglaciations were associated with rapid rises in relative sea level (Rohling et al., 1998). Between the Late Saalian and Ear- 


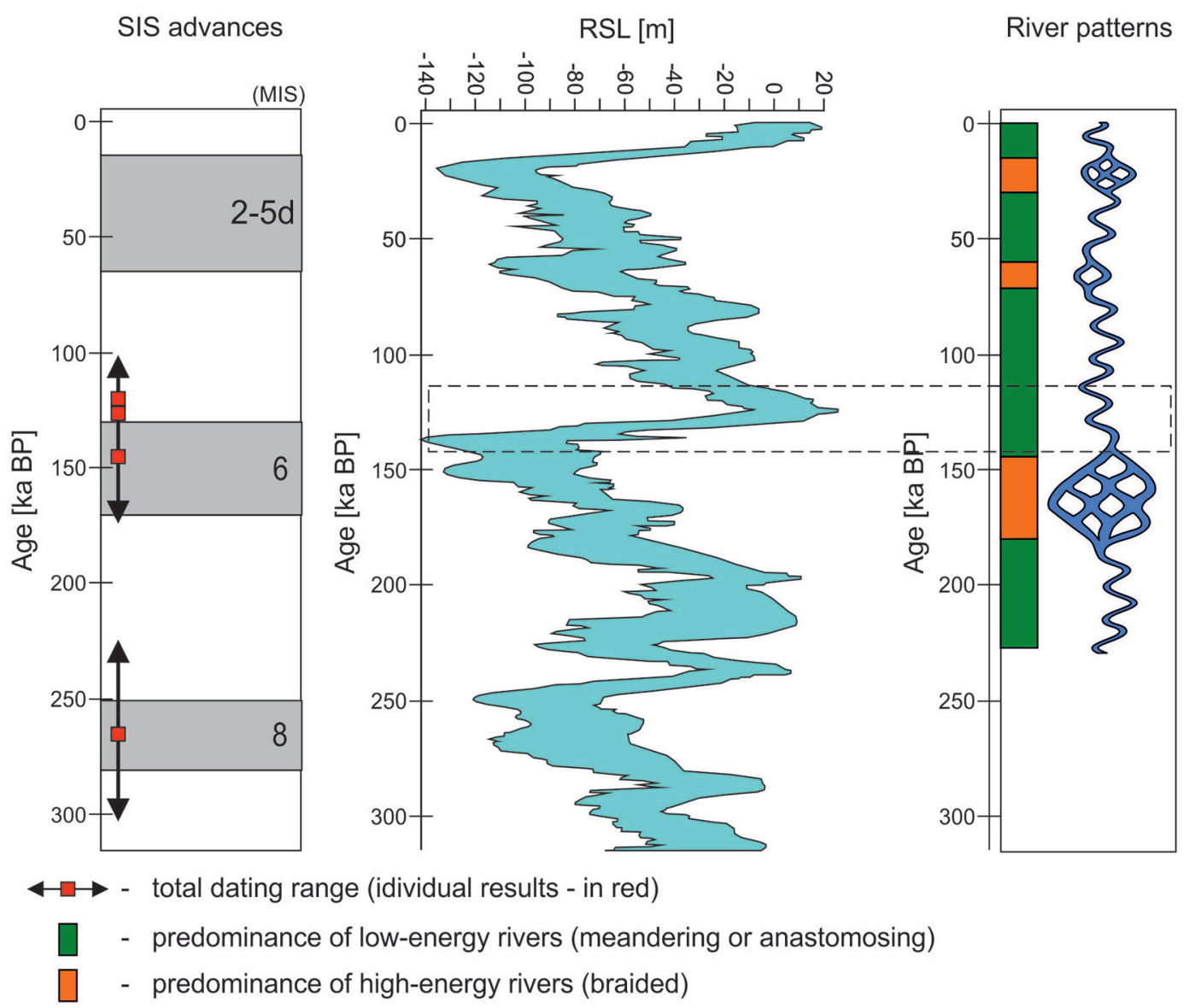

Fig. 5. Compilation of data on advances of the Scandinavian Ice Sheet in Poland, associated relative sea level (RSL) changes and response of fluvial pattern evolution. Glacial episodes (grey colour), correlated with marine isotope stages (MIS), are based on the revised stratigraphic scheme of the Pleistocene of Poland (Lindner et al., 2013). The graph of RSL changes is based on Rohling et al. (2012), who used curves of Waelbroeck et al. (2002), De Boer et al. (2010) and Rohling et al. (2009). Fluvial pattern evolution refers to Central Europe. Data based on the present work and on Krzyszkowski (1990), Mol (2000) and Zieliński (2007). The timespan of processes described in the present study is marked by a dashed rectangle.

ly Eemian sea level rose with a minimum value of 80 $\mathrm{m}$, probably more (about 100-120 m; Rohling et al., 2012, fig. 5). Such a great change led to formation of the Eem Sea, and later, rapid marine transgression onto lowlands in the south (Makowska, 2009; Marks et al., 2014). Deglaciation also led to vertical crustal movements. The Baltic basin was uplifted as a consequence of glacio-isostatic rebound (Forsstrom et al., 1988). During the Late Saalian/Early Eemian the study area situated near the margin of the ice mass. This suggests that the rate of glacio-isostatic uplifting was similar to that during the Late Weichselian/ Holocene period, probably surpassing modern rate, which is estimated in the central part of Baltic basin to be 2-4 mm per annum (Ekman \& Makinen, 1996; Rosentau et al., 2012).
Sea level changes and crustal movements impacted geological processes and the sedimentary record in the Baltic region, including terrestrial environments (Van Andel \& Tzedakis, 1996; Marks, 2005; Mojski, 2005). The fluvial deposits studied here showed an aggradation stacking pattern of a downstream fluvial system with well-preserved point-bar cycles. The rate of sea level rise must have compensated the rate of glacio-isostatic uplift of the intracontinental basin to fulfil accommodation space requirements (Coe \& Church, 2005a, b). Therefore, strong aggradation with a high preservation potential of point-bar sediments must have resulted mainly from relative sea level rise controlled by global climate changes during the Late Saalian/ Early Eemian. 


\section{Conclusions}

The present study provides an interpretation and discussion of Pleistocene fluvial sediments in the Chłapowo cliff section. Lithofacies and palaeocurrent analyses, as well as preliminary dating, provide the basis for the following conclusions.

The sediments investigated formed in a meandering river environment with river outflow directed to the northwest. According to results of palaeohydraulic analysis, the river is interpreted to have been of medium scale, with a mean depth of $c$. 1.6-3.3 m, a mean palaeoflow velocity of $1-2.3 \mathrm{~m} / \mathrm{s}$ and a sinuosity of 1.5 . Formation of a meandering river pattern was made possible by a low-energy gradient and moderate flow amplitudes.

Fieldwork revealed several specific records of point-bars: 1) sharp erosive bases of successions (i.e., palaeochannel bottom surface); 2) general lithofacies succession of GSt (St, Sp) $\rightarrow \mathrm{Sl} \rightarrow \mathrm{SFrc} \rightarrow \mathrm{Fm}(\mathrm{SFr})$ and related architectural elements: channel/sandy bedforms $\mathrm{CH} / \mathrm{SB} \rightarrow$ lateral accretion deposits LA $\rightarrow$ floodplain fines with crevasse splays FF (CS); 3) scattered palaeocurrent directions within cycles; 4) abundance of muddy (floodplain-derived) intraclasts and their upward-decreasing content in channel facies.

Distinction of a meandering river pattern is easier if the upper portions of sedimentary cycles are fully preserved. Textural and mineralogical analyses appear to be useful in identification of meandering river environment as well, revealing the following upward trends within point-bar sediments: 1) grain size fining; 2) increasing content of less resistant heavy minerals; 3 ) decreasing content of opaque heavy minerals.

The river functioned at the end of the Saalian and at the start of the Eemian, shortly after the retreat of the Scandinavian Ice Sheet, as deduced from TL dating and overlying position of the Weichselian till. In our opinion the good preservation and strong aggradation of point-bar cycles were related to a rapid relative base level rise. The influence of sea level rise on the formation of the river pattern probably was more important than the direct impact of climate change.

Identification of a Late Saalian/Early Eemian meandering river system with outflow directed to the north-northwest implies that existing models of the extent of the Eem Sea and of the regional river network may need revision by addition of data from other study sites.

\section{Acknowledgements}

We thank participants of the $16^{\text {th }}$ Field Sedimentological Workshop (2014) for their interesting comments on interpretation of fluvial strata, and journal reviewers for suggestions which led to the improvement of an typescript. Laboratory analyses were financially supported by the Department of Geomorphology and Quaternary Geology at the University of Gdańsk.

\section{References}

Allen, J.R.L., 1964. A review of the origin and characteristics of recent alluvial sediments. Sedimentology 5, 89-191.

Allen, P. \& Mange-Rajetzky, M., 1982. Sediment dispersal and palaeohydraulics of Oligocene rivers in the eastern Ebro Basin. Sedimentology 29, 705-716.

Ashley, G.M., 1990. Classification of large-scale subaqueous bedforms: a new look at an old problem. Journal of Sedimentary Petrology 60, 160-172.

Blum, M., Martin, J., Milliken, K. \& Garvin, M., 2013. Paleovalley systems: Insights from Quaternary analogs and experiments. Earth Science Reviews 116, 128-169.

Blum, M.D. \& Tornqvist, T.E., 2000. Fluvial response to climate and sea-level change: a review and look forward. Sedimentology 47, 2-48.

Bridge, J.S., Jalfin, G.A. \& Georgieff, S.M., 2000. Geometry, lithofacies, and spatial distribution of Cretaceous fluvial sandstone bodies, San Jorge Basin, Argentina: outcrop analog for the hydrocarbon-bearing Chubut Group. Journal of Sedimentary Research 70, 341-359.

Bridge, J.S. \& Mackey, S.D., 1993. A theoretical study of fluvial sandstone body dimensions. [In:] Flint, S.S. \& Bryant, I.D. (Eds), The Geological Modelling of Hydrocarbon Reservoirs and Outcrop Analogues. International Association of Sedimentologists Special Publication 15, 213-236.

Bridge, J.S. \& Tye, R.S., 2000. Interpreting the dimensions of ancient fluvial channel bars, channels, and channel belts from wireline-logs and cores. American Association of Petroleum Geologists Bulletin 84, 1205-1228.

Catuneanu, O., 2006. Principles of sequence stratigraphy. Elsevier, Amsterdam, $375 \mathrm{pp}$.

Coe, A.L. \& Church, K.D., 2005a. Sequence stratigraphy and sea level change. [In:] Coe, A.L. (Ed.), The sedimentary record of sea-level change. Cambridge University Press, Cambridge, 57-98.

Coe, A.L. \& Church, K.D., 2005b. Processes controlling relative sea-level change and sediment supply. [In:] Coe, A.L. (Ed.), The sedimentary record of sea-level change. Cambridge University Press, Cambridge, 99-117.

Collinson, J.D., 1996. Alluvial sediments. [In:] Reading, H.G. (Ed.), Sedimentary environments: Processes, Facies and Stratigraphy, Blackwell, 37-82.

Cotter, E., 1971. Paleoflow characteristics of a Late Cretaceous river in Utah from analysis of sedimentary structures in the Ferron Sandstone. Journal of Sedimentary Petrology 41, 129-138. 
Cowan, E.J., 1991. The large-scale architecture of the fluvial Wetwater Canyon Member, Morrison Formation (Jurassic), San Juan Basin, New Mexico. [In:] Miall, A.D., Tyler, N. (Eds), The three dimensional facies architecture of terrigenous clastic sediments, and its applications for hydrocarbon discovery and recovery. Concepts in Sedimentology and Paleontology 3, 80-93.

Crowley, K.D., 1983. Large-scale bed configurations (macroforms), Platte River Basin, Colorado and Nebraska: Primary structures and formative processes. Geological Society of America Bulletin 94, 117-133.

De Boer, B., Van de Wal, R.S.W., Bintanja, R., Lourens, L.J. \& Tuenter, E., 2010. Cenozoic global ice-volume and temperature simulations with 1-D ice-sheet models forced by benthic delta O-18 records. Annals of Glaciology 51, 23-33.

Ekman, M. \& Makinen, J., 1996. Recent postglacial rebound, gravity change and mantle flow in Fennoscandia. Geophysical Journal International 126, 229-234.

Farrell, K.M., 2001. Geomorphology, facies architecture, and high-resolution, non-marine sequence stratigraphy in avulsion deposits, Cumberland Marshes, Saskatchewan. Sedimentary Geology 139, 93-150.

Fedorowicz, S., 2006. Metodyczne aspekty luminescencyjnego oznaczania wieku osadów neoplejstoceńskich Europy Środkowej [Methodological Aspects of Luminescence Dating of Central European Neopleistocene Deposits]. University of Gdańsk Press, 156 pp. (in Polish, with English abstract)

Fedorowicz, S., Łanczont, M., Bogucki, A., Kusiak, J., Mroczek, P., Adamiec, G., Bluszcz, A., Moska, P. \& Tracz, M., 2013. Loess-paleosol sequence at Korshiv (Ukraine): Chronology based on complementary and parallel dating (TL, OSL), and litho-pedosedimentary analyses. Quaternary International 296, 117-130.

Ferguson, R.I., 1987. Hydraulic and sedimentary controls of channel pattern. [In:] Richards, K.S. (Ed): River channels: environment and process. Blackwell, Oxford, 129-158.

Forsstrom, L., Aalto, M., Eronen, M. \& Grönlund, T., 1988. Stratigraphic evidence for Eemian crustal movements and relative sea-level changes in eastern Fennoscandia. Palaeogeography, Palaeoclimatology, Palaeoecology 68, 317-335.

Funder S., Demidov I. \& Yelovicheva Y., 2002. Hydrography and mollusc faunas of the Baltic and the White Sea-North Sea seaway in the Eemian. Palaeogeography, Palaeoclimatology, Palaeoecology 184, 275-304.

Fustic M., Hubbard S.M., Spencer R., Smith D.G., Leckie D.A., Bennett B. \& Larter S., 2012. Recognition of down-valley translation in tidally influenced meandering fluvial deposits, Athabasca Oil Sands (Cretaceous), Alberta, Canada. Marine and Petroleum Geology 29, 219-232.

Ghazi, F. \& Mountney, N.P., 2009. Facies and architectural element analysis of a meandering fluvial succession: The Permian Warchha Sandstone, Slat Range, Pakistan. Sedimentary Geology 221, 88-126.

Ghinassi, M., 2011. Chute channels in the Holocene highsinuosity river deposits of the Firenze plain, Tuscany, Italy. Sedimentology 58, 618-642.
Ghinassi, M., Nemec, W., Aldinucci, M., Nehyba, S., Özaksoy, V. \& Fidolini, F., 2014. Plan-form evolution of ancient meandering rivers reconstructed from longitudinal outcrop sections. Sedimentology 61, 952-977.

Gibbard, P.L. \& Lewin, J., 2002. Climate and related controls on interglacial fluvial sedimentation in lowland Britain. Sedimentary Geology 151, 187-210.

Grenfell, M.C., Nicholas, A.P. \& Aalto, R., 2014. Mediative adjustment of river dynamics: The role of chute channels in tropical sand-bed meandering rivers. Sedimentary Geology 301, 93-106.

Hartley, A.J., Weissmann, G.S., Nichols, G.J. \& Warwick, G.L., 2010. Large distributive fluvial systems: characteristics, distribution and controls on development. Journal of Sedimentary Research 80, 167-183.

Head, M.J., Seidenkrantz, M.S., Janczyk-Kopikowa, Z., Marks, L. \& Gibbard, P.L., 2005. Last Interglacial (Eemian) hydrographic conditions in the southeastern Baltic Sea, NE Europe, based on dinoflagellate cysts. Quaternary International 130, 3-30.

Huisink, M., de Moor, J.J.W., Kasse, C. \& Virtanen, T., 2002. Factors influencing periglacial morphology in the northern European Russian tundra and taiga. Earth Surface Processes and Landforms 27, 1223-1235.

Ito, M., Matsukawa, M., Saito, T. \& Nichols, D.J., 2006. Facies architecture and paleohydrology of a synrift succession in the Early Cretaceous Choyr Basin, southeastern Mongolia. Cretaceous Research 27, 226-240.

Kasse, C., Vanderberghe, J., Van Huissteden, J., Bohncke, S.J.P. \& Bos, J.A.A., 2003. Sensitivity of Weichselian fluvial systems to climate change (Nochten mine, eastern Germany). Quaternary Science Reviews 22, 2141-2156.

Khan, Z.A. \& Tewari, R.C., 2011. Paleochannel and paleohydrology of a Middle Siwalik (Pliocene) fluvial system, northern India. Journal of Earth System Science 3, 531-543.

Kozarski, S. \& Rotnicki, K., 1977. Valley floors changes of river channel patterns in the north Polish Plain during the late Wurm and Holocene. Quaestiones Geographicae 4, 51-93.

Kozarski, S., Gonera, P. \& Antczak, B., 1988. Valley floor development and paleohydrological changes: the Late Vistulian and Holocene history of the Warta river (Poland). [In:] Lang, G. \& Schluchter, C. (Eds), Lake, Mire and River Environments during the Last 15000 Years. Balkema, Rotterdam, 185-203.

Kramarska, R., Uścinowicz, S. \& Zachowicz, J., 2002. Kenozoik południowego Bałtyku - wybrane zagadnienia [Cenozoic of Southern Baltic - selected problems]. Przeglad Geologiczny 50, 709-716 (in Polish with English summary).

Kramarska, R., Kasiński J.R. \& Czapowski G., 2008. Węgle brunatne w profile klifu Chłapowskiego [Lignites in Chłapowo cliff profile]. [In:] Kramarska R. \& Jurys L. (Ed.), Dokumentowanie i ochrona złóż kopalin XI [Exploration and protection of raw material deposits XI], Gdańsk, 9-14.

Krzyszkowski, D., 1990. Middle and Late Weichselian stratigraphy and palaeoenvironments in central Poland. Boreas 19, 333-350. 
Leleu, S., Hartley, A.J. \& Williams, B.P., 2009. Large-scale alluvial architecture and correlation in a Triassic pebbly braided river system, lower Wolfville Formation (Fundy Basin, Nova Scotia, Canada). Journal of Sedimentary Research 79, 265-286.

Leopold, L.B. \& Wolman, M.G., 1957a. River Channel Patterns: Braided, Meandering and Straight, Physiographic and hydraulic studies of rivers. Geological Survey Professional Paper 282 B, 39-85.

Leopold, L.B. \& Wolman, M.G., 1957b. River flood plains: Some observations on their formation, physiographic and hydraulic studies of rivers. Geological Survey Professional Paper 282 C, 87-109.

Leopold, L.B. \& Wolman, M.G., 1960. River meanders. Bulletin of the Geological Society of America 71, 769-794.

Lindner, L., Marks, L. \& Nita, M., 2013. Climatostratigraphy of interglacials in Poland: Middle and Upper Pleistocene lower boundaries from a Polish perspective. Quaternary International 292, 113-123.

Maizels, J.K., 1983. Paleovelocity and paleodischarge determination for coarse gravel deposits. [In:] Gregory, K.J. (Ed.), Background to Paleohydrology. Wiley, Chichester, 101-139.

Makowska, A., 2009. Międzymorenowa formacja dolnopowiślańska na tle budowy osadów plejstoceńskich pomorza nadwiślańskiego i jej rozwój w młodszym plejstocenie. [Intermorainic Lower Vistula Formation against the background of geological structure of Pleistocene deposits in Vistula Pomerania, and its development during the Younger Pleistocene]. Biuletyn PIG 437, 59-124 (in Polish with English summary).

Mange M.A. \& Maurer F.W., 1992. Heavy minerals in colour. Chapman \& Hall, London, 147 pp.

Marks, L., 2005. Pleistocene river systems in the southern peribaltic area as indication of interglacial sea level changes in the Baltic Basin. Quaternary International 130, 43-48.

Marks, L., Gałązka, D., Krzymińska, J., Nita, M., Stachowicz-Rybka, R., Witkowski, A., Woronko, B. \& Dobosz, S. 2014. Marine transgressions during Eemian in northern Poland: A high resolution record from the type section at Cierpięta. Quaternary International, 328-329, 45-59.

Marzec, M. \& Woźny, E., 1972. Litologia i stratygrafia utworów trzeciorzędu okolic Jastrzębiej Góry koło Pucka [Lithology and stratigraphy of Teritary deposits in the neighborhood of Jastrzębia Góra near Puck]. Przeglad Geologiczny 20, 562-570 (in Polish)

Miall, A.D., 1985. Architectural-element analysis: A new method of facies analysis applied to fluvial deposits. Earth-Science Reviews 22, 261-308.

Miall, A.D., 1996. The geology of fluvial deposits. Sedimentary facies, basin analysis and petroleum geology. Springer, New York, 582 pp.

Mojski, J.E., 2005. Ziemie polskie w czwartorzędzie. Zarys morfogenezy [Polish area in Quaternary. Outline of morphogenesis]. Polish Geological Institute, Warszawa, 404 pp.

Mol, J., Vandenberghe, J. \& Kasse, C., 2000. River response to variations of periglacial climate in mid-latitude Europe. Geomorphology 33, 131-148.
Morton, R.A. \& Donaldson, A.C., 1978. The Guadalupe River and Delta of Texas - a modern analogue for some ancient fluvial-deltaic systems. [In:] Miall, A.D. (Ed.), Fluvial sedimentology, Canadian Society of Petroleum Geologists Memoir 5, 773-787.

Moskalewicz, D. \& Sokołowski, R.J., 2014. Kenozoiczne sekwencje fluwialne w klifie chłapowskim [Cenozoic fluvial sequences in the Chłapowo cliff section]. [In:] Sokołowski, R.J., (Ed.), Ewolucja środowisk sedymentacyjnych regionu Pobrzeża Kaszubskiego [Evolution of sedimentary environments in Pobrzeże Kaszubskie region]. University of Gdansk, 39-49 (in Polish).

Nanson, G.C., 1980. Point bar and floodplain formation of the meandering Beatton River, northeastern British Columbia, Canada. Sedimentology 27, 3-29.

Olszak, I., 1996. Wiek TL osadów czwartorzędowych wschodniej części klifu Chłapowskiego [TL age of Quaternary sediments of the eastern part of Chłapowo cliff]. [In:] Kostrzewski, A. (Ed.), Geneza, litologia i stratygrafia utworów czwartorzędowych [Genesis, lithology and stratigraphy of Quaternary deposits] 2, 231-239 (in Polish with English summary).

Rohling, E.J., Grant, K., Bolshaw, M., Roberts, A.P., Siddall, M., Hemleben, Ch. \& Kucera, M., 2009. Antarctic temperature and global sea level closely coupled over the past five glacial cycles. Nature Geoscience 2, 500-504.

Rohling, E.J., Medina-Elizalde, M., Shepherd, J.G., Siddall, M. \& Stanford, J.D., 2012. Sea Surface and HighLatitude Temperature Sensitivity to Radiative Forcing of Climate over Several Glacial Cycles. Journal of Climate 25, 1635-1656.

Rohling, E.M., Fenton, M., Jorissen, F.J., Bertrand, P., Ganssen, G. \& Caulet, J.P., 1998. Magnitudes of sealevel lowstands of the past 500,000 years. Nature 394, 162-165.

Rosentau, A., Harff, J., Oja, T. \& Meyer, M., 2012. Postglacial rebound and relative sea level changes in the Baltic Sea since the Littorina transgression. Baltica 25, 113-120.

Rust, B.R., 1978. A classification of alluvial channel systems. [In:] Miall, A.D. (Ed.), Fluvial Sedimentology. Canadian Society of Petroleum Geologists Memoir 5, Calgary, 187-198.

Salamon T. \& Zieliński T., 2010. Unusual development of sandur sedimentary succession, an example from the Pleistocene of S Poland. Geologos 16, 83-99.

Schumm, S.A., 1972. Fluvial paleochannels. [In:] Rigby, J.K. \& Walton, W.K. (Eds), Recognition of Ancient Sedimentary Environments, SEPM Special Publications $16,98-107$.

Stewart, D.J., 1981. A meander-belt sandstone of the Lower Cretaceous of S England. Sedimentology 28, 1-20.

Teisseyre, A.K., 1985. Mady dolin sudeckich. Część I: Ogólna charakterystyka środowiskowa (na przykładzie zlewni górnego Bobru) [Alluvia of Sudeten rivers. Part I: General environmental description (an example of the upper Bóbr River Basin)]. Geologia Sudetica 20, 113-195 [In Polish with English summary].

Teisseyre, A.K., 1991. Klasyfikacja rzek w świetle analizy systemu fluwialnego i geometrii hydraulicznej. [Clas- 
sification of rivers in the light of fluvial and hydraulic geometry analyses]. Acta Universitatis Wratislaviensis, Prace Geologiczno-Mineralogiczne 22, 210 pp. [In Polish with English summary].

Todd, S.P. \& Went, D.J., 1991. Lateral migration of sandbed rivers: examples from the Devonian Glashabeg Formation, SW Ireland and the Cambrian Aldemey Sandstone Formation. Channel Islands. Sedimentology 38, 997-1020.

Toucanne, S., Zaragosi, S., Bourillet, J.F., Gibbard, P.L., Eynaud, F., Giraudeau, J., Turon, J.L., Cremer, M., Cortijo, E., Martinez, P. \& Rossignol, L., 2009. A 1.2 Ma record of glaciation and fluvial discharge from the West European Atlantic margin. Quaternary Science Reviews 28, 2974-2981.

Tucker, M.E., 2003. Sedimentary rocks in the field. Wiley, Chichester, $234 \mathrm{pp}$.

Van Andel, T.H. \& Tzedakis, P.C., 1996. Palaeolithic landscapes of Europe and environs, 150,000-25,000 years ago: an overview. Quaternary Science Reviews 15, 481500.

Vandenberghe, J., 2001. A typology of Pleistocene coldbased rivers. Quaternary International 79, 111-121.

Vandenberghe, J., 2003. Climate forcing of fluvial system development: an evolution of ideas. Quaternary Science Reviews 22, 2053-2060.

Vanderberghe, J. \& Woo, M., 2002. Modern and ancient periglacial river types. Progress in Physical Geography 26, 479-506.

Van Huissteden, J. \& Kasse, C., 2001. Detection of rapid climate change in Last Glacial fluvial successions in The Netherlands. Global and Planetary Change 28, 319339.

Waelbroeck, C., Labeyrie, L., Michel, E., Duplessy, J.C., McManus, J.F., Lambeck, K., Balbon, E. \& Labrach- erie, M., 2002. Sea-level and deep water temperature changes derived from benthic foraminifera isotopic records. Quaternary Science Reviews 21, 295-305.

Weckwerth, P. \& Chabowski, M., 2013. Heavy minerals as a tool to reconstruct river activity during the Weichselian glaciation (Torun Basin, Poland). Geo$\log$ os 19, 25-46.

Williams, G.P., 1984. Paleohydrologic equations for rivers. [In:] Costa, J.E. \& Fleisher, P.J. (Eds), Developments and Applications of Geomorphology. Springer, New York, 343-367.

Williams, G.P., 1986. River meanders and channel size. Journal of Hydrology 88, 147-164.

Zieliński, T., 1998. Litofacjalna identyfikacja osadów rzecznych [Lithofacial identification of alluvial sediments], [In:] E. Mycielska-Dowgiałło (Ed.): Struktury sedymentacyjne sedymentacyjne $i$ postsedymentacyjne w osadach czwartorzędowych [Sedimentary and postsedimentary structures in Quaternary sediments and their value for interpretation], University of Warsaw Press, 195-260 (in Polish with English summary)

Zieliński T., 2007. The Pleistocene climate-controlled fluvial sedimentary record in the Bełchatów mine (central Poland). Sedimentary Geology 193, 203-209.

Zieliński, T., 2014. Sedymentologia. Osady rzek i jezior [Sedimentology. Deposits of rivers and lakes]. Wydawnictwo Naukowe UAM, Poznań, 1-594.

Zieliński, T. \& Goździk, J., 2001, Paleoenvironmental interpretation of a Pleistocene alluvial succession in central Poland: sedimentary facies analysis as a tool for paleoclimatic inferences. Boreas 30, 240-253.

Manuscript submitted 25 March 2015 Revision accepted 3 February 2016 